\title{
Down, but not out: Recent decline of Berg-Breede River whitefish (Barbus andrewi) in the upper Hex River, South Africa
}

\begin{tabular}{|c|c|}
\hline \multicolumn{2}{|c|}{$\begin{array}{l}\text { Authors: } \\
\text { Jeremy M. Shelton } \\
\text { N. Dean Impson }{ }^{4} \\
\text { Shaun Graham }{ }^{1} \\
\text { Karen J. Esler }^{1,2} \text { (D) }\end{array}$} \\
\hline $\begin{array}{l}\text { Affiliations: } \\
{ }^{1} \text { Department } c \\
\text { Ecology and Er } \\
\text { Stellenbosch } L \\
\text { South Africa }\end{array}$ & $\begin{array}{l}\text { f Conservation } \\
\text { tomology, } \\
\text { Jniversity, }\end{array}$ \\
\hline $\begin{array}{l}{ }^{2} \text { Centre of Exc } \\
\text { Invasion Biolo } \\
\text { Stellenbosch } 4 \\
\text { South Africa }\end{array}$ & $\begin{array}{l}\text { ellence for } \\
\text { gy, } \\
\text { Jniversity, }\end{array}$ \\
\hline $\begin{array}{l}{ }^{3} \text { Freshwater R } \\
\text { Kommetjie, So }\end{array}$ & $\begin{array}{l}\text { esearch Centre, } \\
\text { uth Africa }\end{array}$ \\
\hline $\begin{array}{l}{ }^{4} \text { CapeNature } S \\
\text { Services, Stelle } \\
\text { South Africa }\end{array}$ & $\begin{array}{l}\text { cientific } \\
\text { enbosch, }\end{array}$ \\
\hline $\begin{array}{l}\text { Correspondin } \\
\text { Jeremy Shelto } \\
\text { jeremy@frcsa. }\end{array}$ & $\begin{array}{l}\text { g author: } \\
\text { n, } \\
\text { org.za }\end{array}$ \\
\hline $\begin{array}{l}\text { Dates: } \\
\text { Received: } 22 \text { A } \\
\text { Accepted: } 14 \\
\text { Published: } 28\end{array}$ & $\begin{array}{l}\text { pr. } 2016 \\
\text { Jct. } 2016 \\
\text { Mar. } 2017\end{array}$ \\
\hline $\begin{array}{l}\text { How to cite th } \\
\text { Shelton, J.M., } \\
\text { Graham, S. \& } \\
\text { 'Down, but no } \\
\text { decline of Ber } \\
\text { whitefish (Bar } \\
\text { the upper Hex } \\
\text { Africa', Koedoe } \\
\text { https://doi.org } \\
\text { koedoe.v59i1. }\end{array}$ & $\begin{array}{l}\text { is article: } \\
\text { Impson, N.D., } \\
\text { Esler, K.J., 2017, } \\
\text { t out: Recent } \\
\text { g-Breede River } \\
\text { bus andrewi) in } \\
\text { River, South } \\
59(1) \text {, a1398. } \\
\text { /10.4102/ } \\
1398\end{array}$ \\
\hline $\begin{array}{l}\text { Copyright: } \\
\text { (C) 2017. The A } \\
\text { Licensee: AOS } \\
\text { is licensed unc } \\
\text { Creative Comn } \\
\text { Attribution Lic }\end{array}$ & $\begin{array}{l}\text { uthors. } \\
\text { IS. This work } \\
\text { ler the } \\
\text { nons } \\
\text { ense. }\end{array}$ \\
\hline Read online: & \\
\hline 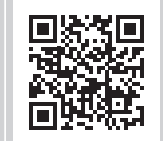 & $\begin{array}{l}\text { Scan this QR } \\
\text { code with your } \\
\text { smart phone or } \\
\text { mobile device } \\
\text { to read online. }\end{array}$ \\
\hline
\end{tabular}

The Berg-Breede River whitefish, Barbus andrewi, an endangered Cape Floristic Region endemic, was once widespread in both the Berg and Breede River catchments. However, its distribution has been strongly reduced, apparently by human-related activities, over the last century, and the Hex River now contains one of the last recruiting populations within its native range. This population was last surveyed by Christie who found that the species occurred in six pools over a 9-km stretch of the upper Hex River. We re-surveyed fish populations at Christie's sites in 2015 to evaluate differences in the fish community between 2002 and 2015. Our data indicated that the distribution of $B$. andrewi in the Hex River has declined from six to four pools and that its density in the study area in 2015 ( 0.57 fish per $100 \mathrm{~m}^{2} \pm 0.31$ fish per 100 $\mathrm{m}^{2}$ ) was more than fivefold lower than that recorded in 2002 (3.39 fish per $100 \mathrm{~m}^{2} \pm 1.40$ fish per $\left.100 \mathrm{~m}^{2}\right)$. Moreover, small size classes of $B$. andrewi $(<10 \mathrm{~cm})$ were largely absent in 2015, indicating recruitment failure in recent years. Habitat degradation, exacerbated by a severe flood in 2008, and recent invasions by predatory non-native fishes (smallmouth bass, Micropterus dolomieu and sharptooth catfish, Clarias gariepinus) are identified as likely causes of this decline. Cape kurper, Sandelia capensis, another native species, was relatively common in 2002 but not recorded in 2015, whereas the density of native Breede River redfin, Pseudobarbus burchelli, was higher in 2015 than in 2002. Urgent conservation actions including managing non-native fish invasions and mitigating agricultural impacts on aquatic habitat are required to prevent further decline, and possible extirpation, of the Hex River population of B. andrewi.

Conservation implications: Urgent conservation actions including preventing further increases in the abundance and distribution of non-native fishes, and improving habitat and water quality through mitigating agricultural impacts, are required to prevent further decline, and possible extirpation, of the Hex River population of B. andrewi.

\section{Introduction}

The freshwater fish fauna of the Cape Floristic Region (CFR) is characterised by low diversity (only 21 species), but high levels of endemism (De Moor \& Day 2013). These fishes have evolved in rivers with clear, acidic waters that lack piscivorous fishes and are highly susceptible to humaninduced disturbances such as water abstraction, bank modification, eutrophication and the introduction of non-native fishes (Impson \& Hamman 2000; Tweddle et al. 2009). Currently, 13 of the 17 recognised endemic freshwater fish species are listed as endangered or vulnerable by the International Union for Conservation of Nature (IUCN; Tweddle et al. 2009).

The Berg-Breede River whitefish, Barbus andrewi (Barnard 1937) (Figure 1), is one of four large endemic cyprinid fishes in the CFR, capable of reaching $>60 \mathrm{~cm}$ in length and a mass of $>3 \mathrm{~kg}$ (Impson 2001). Historically, B. andrewi was abundant in both the Berg and Breede River systems (Harrison 1952), but has since experienced dramatic declines in abundance and distribution in both systems, to the point where the Berg River population was declared extinct (Clark, Impson \& Rall 2009; Impson 2001), and the species has consequently been listed as Endangered in the IUCN Red List of Threatened Species (Tweddle et al. 2009). One of the last actively recruiting riverine populations of B. andrewi occurs in the upper Hex River, a tributary of the Breede River between the towns of De Doorns and Worcester in the CFR (Figure 2). In 2002, Christie surveyed fish populations in the upper Hex River and found that B. andrewi was relatively abundant (mean $\pm \mathrm{SE}$ density between 01.99 fish per $100 \mathrm{~m}^{2} \pm 0.33$ fish per $100 \mathrm{~m}^{2}$ and 25.00 fish per $100 \mathrm{~m}^{2} \pm 3.69$ fish per $100 \mathrm{~m}^{2}$ ) in four pools above Glen Heatlie causeway, but less common below it (mean \pm SE density between 0.12 fish per $100 \mathrm{~m}^{2} \pm 0.01$ fish per $100 \mathrm{~m}^{2}$ and 0.61 fish per $100 \mathrm{~m}^{2} \pm 0.20$ fish per $100 \mathrm{~m}^{2}$ ) where non-native smallmouth bass Micropterus dolomieu (Lacepède, 1802) was present. That study 


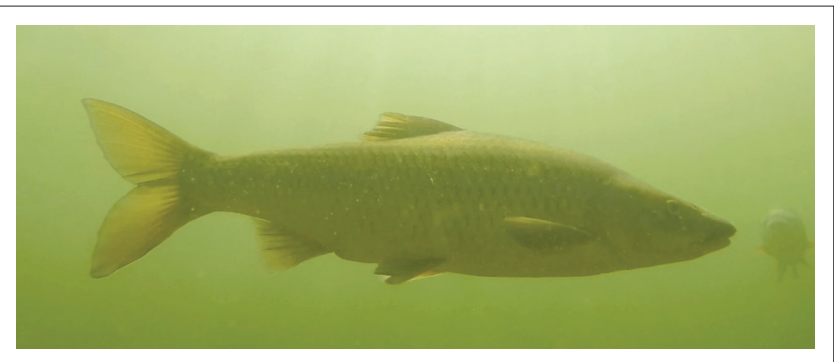

Source: Photograph by S. Graham

FIGURE 1: An adult (approximate length $50 \mathrm{~cm}$ ) Barbus andrewi at Site 5 in the upper Hex River during the 2015 survey.

also recorded the indigenous species Breede River redfin, Pseudobarbus burchelli (Smith, 1841) and Cape kurper, Sandelia capensis (Cuvier, 1831), above Glen Heatlie causeway, as well as non-native rainbow trout, Oncorhynchus mykiss (Walbaum, 1792), which co-occurred in pools with native fish species both above and below the causeway.

The upper Hex River has been listed as a Fish Critical Biodiversity Area in the Atlas of National Freshwater Ecosystem Priority Areas (Nel et al. 2011) because of its conservation importance for $B$. andrewi and associated indigenous fish species. However, the population of $B$. andrewi is under growing threat from habitat degradation (compounded by a major flood in November 2008) and introductions of non-native fishes (Impson 2009), circumstances which highlighted the need for an updated fish survey in the upper Hex River. In this study, we re-surveyed the sites sampled by Christie (2002) to assess changes in abundance and distribution of $B$. andrewi, as well as other fish species, in the upper Hex River.

\section{Materials}

\section{Study site}

The upper Hex River is a perennial, cobble-bed dominated system consisting primarily of riffles and glides interspersed with occasional pools. Pools range in depth from $1 \mathrm{~m}$ to $3 \mathrm{~m}$, and the water in dry season (October - March) is clear enough that pool bottoms can be seen at all depths with a mask and snorkel. The upper catchment is intensively farmed for vineyards and citrus, and the river is exposed to a range of associated impacts. For example, a wastewater treatment plant at De Doorns discharges into the Hex River upstream, and the river also experiences heavy water abstraction in summer which substantially reduces flow and habitat availability downstream. Furthermore, a major flood in November 2008 caused extensive bank collapse and sedimentation in the river channel which likely compounded such impacts (Holloway, Fortune \& Chasi 2010).

\section{Approach}

To assess the status of the $B$. andrewi population in the upper Hex River, we sampled the same 10 pools surveyed by Christie (2002). These pools were located along a 9-km stretch of the river between the N1 road bridge and Kanetvlei
Farm (Figure 2). We specifically followed the same methodology used by Christie (2002) and conducted our sampling during autumn, at the same time of the year (26 March - 04 April in 2002 and 21 March - 05 April in 2015), to facilitate comparisons of fish abundance and distribution. Fish abundance estimates were based on two-pass snorkel surveys, and all fish sighted were identified to species, enumerated and recorded on a plexiglass slate. Differences in factors like water clarity, habitat complexity and fish behaviours between 2002 and 2015 could potentially influence fish detection probability. However, visual methods such as snorkeling have been shown to provide robust estimates of fish abundance in clear CFR streams (Ellender et al. 2012). Fish length (total length [TL], cm) was estimated for $B$. andrewi using a ruler attached to the slate. Fish assemblages present in the Hex River upstream of Site 1 and the Amandel River were investigated by single pass snorkeling prior to the study, but no B. andrewi were recorded (J.M. Shelton unpubl. data 2015). Pool length was measured (m) and pool width $(\mathrm{m})$ determined using three evenly spaced transects.

\section{Analysis}

Pool area $\left(\mathrm{m}^{2}\right)$ was calculated by multiplying mean width by length, which was used to convert fish abundances to densities (fish per $\mathrm{m}^{2}$ ). Densities (mean $\pm \mathrm{SE}$ ) of each species in each pool were estimated from the two snorkel passes, and density estimates were also made for each species above and below Glen Heatlie causeway, as well as for the study area as a whole for both the 2002 and 2015 data sets. We tested whether fish abundance differed between 2002 and 2015 with a zero-inflated negative binomial regression model implemented using the 'pscl' implemented in R version 3.0 (R Core Team 2013). Zero-inflated negative binomial models are appropriate for count data with an excess of zeros (Hall 2000).

\section{Results}

There have been considerable changes in the composition, distribution and abundance of fishes in the upper Hex River since Christie's (2002) survey (Table 1). Barbus andrewi density was more than fivefold lower in 2015 (0.57 fish per $100 \mathrm{~m}^{2} \pm$ 0.31 fish per $100 \mathrm{~m}^{2}$ ) than in 2002 (3.39 fish per $100 \mathrm{~m}^{2} \pm 1.40$ fish per $100 \mathrm{~m}^{2}$ ), with the vast majority of fish being recorded in pools upstream of Glen Heatlie causeway in both years (Figure 2). Pool occupancy decreased from six pools in 2002 to four pools in 2015, and pools occupied during 2015 were not necessarily the same as those occupied in 2002. There was also a clear difference in the size structure of $B$. andrewi between the years, in that intermediate size classes $(10 \mathrm{~cm}$ $30 \mathrm{~cm}$ ) dominated in 2015, with relatively few fish smaller than $10 \mathrm{~cm}$ or larger than $30 \mathrm{~cm}$ compared to the 2002 records (Figure 3). Sandelia capensis, while present in all pools surveyed above Glen Heatlie causeway in 2002 (0.66 fish per $100 \mathrm{~m}^{2} \pm 0.30$ fish per $100 \mathrm{~m}^{2}$ ), was not recorded in any pools in 2015. On the contrary, P. burchelli density in 2015 (11.69 fish per $100 \mathrm{~m}^{2} \pm 4.17$ fish per $100 \mathrm{~m}^{2}$ ) was approximately four times higher than in 2002 (2.60 fish per $100 \mathrm{~m}^{2} \pm 1.07$ fish 


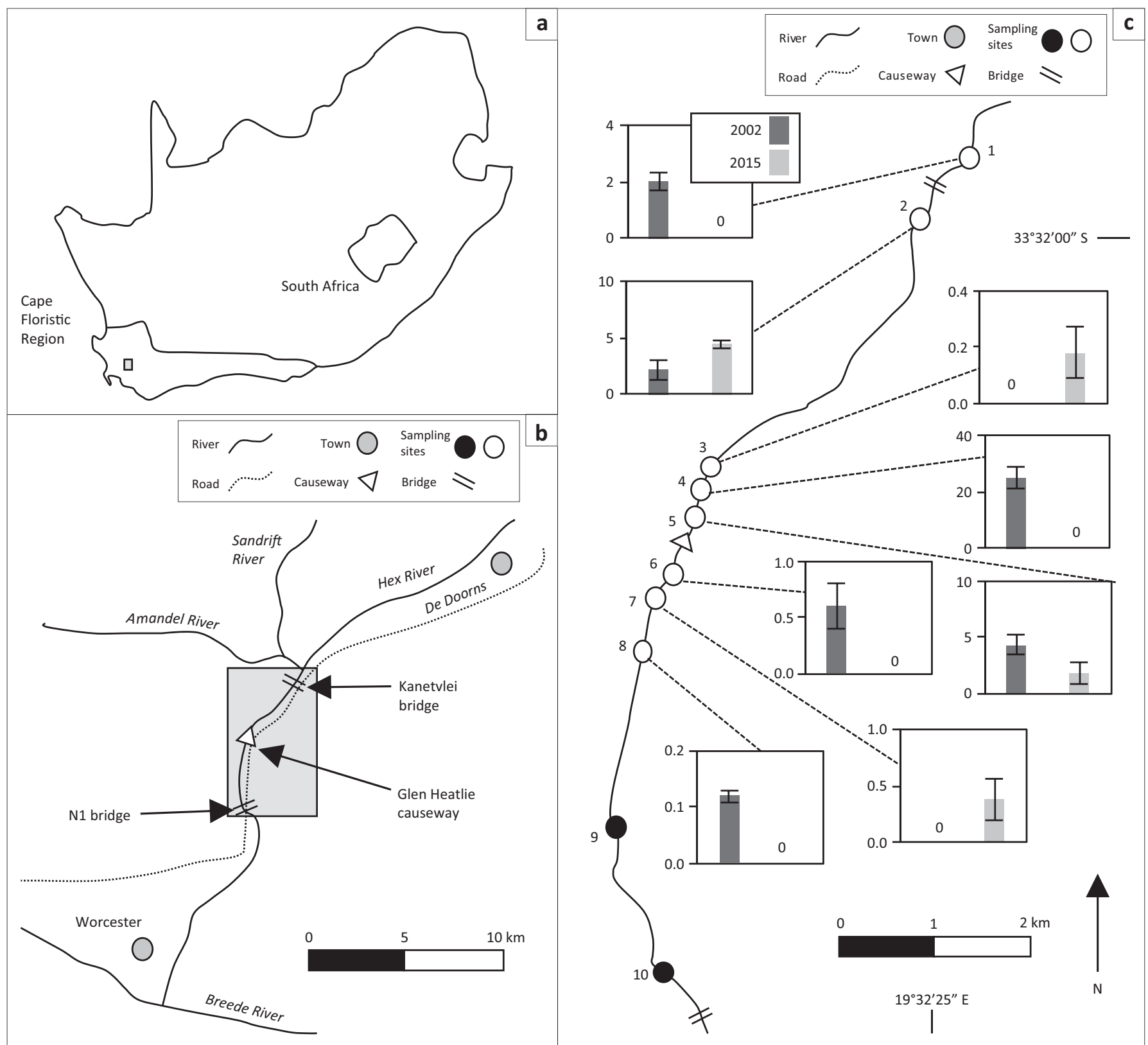

Bar charts indicate Barbus andrewi densities (fish per $100 \mathrm{~m}^{2}$ ) at the sampling sites recorded by Christie (2002, dark grey bars) and during the present (2015, light grey bars) survey. White circles indicate sites where Barbus andrewi were recorded, whereas black circles indicate sites where no Barbus andrewi were recorded.

FIGURE 2: Location of (a) the Hex River catchment in the Cape Floristic Region, South Africa, (b) the location of the study area on the upper Hex River and key features referred to in the text and (c) the location of sampling sites within the study reach.

per $100 \mathrm{~m}^{2}$ ) and was present above the causeway only during both years. $M$. dolomieu density decreased from 2.10 fish per $100 \mathrm{~m}^{2} \pm 0.74$ fish per $100 \mathrm{~m}^{2}$ in 2002 to 0.12 fish per $100 \mathrm{~m}^{2} \pm$ 0.02 fish per $100 \mathrm{~m}^{2}$ in 2015 , but its distribution increased and it was recorded upstream of the causeway (Site 2) in 2015 for the first time. The density $\left(<0.2\right.$ fish per $\left.100 \mathrm{~m}^{2}\right)$ and distribution of $O$. mykiss were similar between years, although it occupied fewer pools above Glen Heatlie causeway in 2015 than in 2002. The non-natives sharptooth catfish, Clarias gariepinus (Burchell, 1822), and common carp, Cyprinus carpio Linnaeus, 1758, were both present in the upper Hex River in 2015, but were not recorded during Christie's (2002) survey. Their abundance was relatively low (approximately 0.01 fish per $100 \mathrm{~m}^{2}$ ), and both species were recorded upstream of Glen Heatlie causeway only.
With the exception of the 'count model' for redfin, which indicates that the increase in density between 2002 and 2015 was significant, the above-described changes in fish densities were not statistically significant (Table 1). However, we advise that these results be treated with caution, given the small sample sizes, high variation in fish abundances between pools and associated low power of the analyses. No statistical analyses were attempted for S. capensis, C. gariepinus and C. carpio given that these species were not present during both sampling periods.

\section{Discussion}

CapeNature data records from 1978 to 1991 (CapeNature, State of Biodiversity [SOB] database) indicate that non-native fishes, with the exception of O. mykiss, were presumed to be 
TABLE 1: Mean \pm SE values for density (fish per $100 \mathrm{~m}^{2}$ ) of fish species recorded using two-pass snorkel surveys at 10 sampling sites, and year totals, in the upper Hex River during 2002 by Christie (2002) and 2015 (the present study).

\begin{tabular}{|c|c|c|c|c|c|c|c|}
\hline \multirow[t]{2}{*}{ Site } & \multicolumn{3}{|c|}{ Native species } & \multicolumn{4}{|c|}{ Non-native species } \\
\hline & $\begin{array}{c}\text { Barbus } \\
\text { andrewi }\end{array}$ & $\begin{array}{c}\text { Pseudobarbus } \\
\text { burchelli }\end{array}$ & $\begin{array}{l}\text { Sandelia } \\
\text { capensis }\end{array}$ & $\begin{array}{c}\text { Micropterus } \\
\text { dolomieu }\end{array}$ & $\begin{array}{c}\text { Oncorhynchus } \\
\text { mykiss }\end{array}$ & $\begin{array}{c}\text { Cyprinus } \\
\text { carpio }\end{array}$ & $\begin{array}{c}\text { Clarias } \\
\text { gariepinus }\end{array}$ \\
\hline \multicolumn{8}{|l|}{2002} \\
\hline 1 & $1.99 \pm 0.33$ & $12.89 \pm 6.48$ & $0.28 \pm 0.15$ & - & $0.34 \pm 0.07$ & - & - \\
\hline 2 & $2.16 \pm 0.86$ & $2.59 \pm 0.86$ & $0.09 \pm 0.00$ & - & $0.35 \pm 0.03$ & - & - \\
\hline 3 & - & $7.25 \pm 5.86$ & $1.18 \pm 0.77$ & - & $0.18 \pm 0.03$ & - & - \\
\hline 4 & $25.00 \pm 3.69$ & $1.64 \pm 1.02$ & $1.79 \pm 1.34$ & - & $0.45 \pm 0.18$ & - & - \\
\hline 5 & $4.31 \pm 0.85$ & $3.95 \pm 2.22$ & $3.26 \pm 2.23$ & - & $0.04 \pm 0.01$ & - & - \\
\hline 6 & $0.61 \pm 0.20$ & - & - & $12.66 \pm 3.06$ & $0.31 \pm 0.09$ & - & - \\
\hline 7 & - & - & - & $2.96 \pm 0.31$ & $0.12 \pm 0.04$ & - & - \\
\hline 8 & $0.12 \pm 0.01$ & - & - & $1.19 \pm 0.17$ & $0.03 \pm 0.01$ & - & - \\
\hline 9 & - & - & - & $1.11 \pm 0.53$ & - & - & - \\
\hline 10 & - & - & - & $3.64 \pm 0.17$ & - & - & - \\
\hline Total & $3.39 \pm 1.40$ & $2.60 \pm 1.07$ & $0.66 \pm 0.30$ & $2.10 \pm 0.74$ & $0.13 \pm 0.03$ & - & - \\
\hline \multicolumn{8}{|l|}{2015} \\
\hline 2 & $4.46 \pm 0.38$ & $34.31 \pm 19.38$ & - & $0.09 \pm 0.05$ & $0.19 \pm 0.09$ & $0.19 \pm 0.09$ & $0.99 \pm 0.40$ \\
\hline 3 & $0.18 \pm 0.09$ & $2.40 \pm 2.05$ & - & - & - & - & - \\
\hline 4 & - & $46.81 \pm 18.05$ & - & - & - & - & - \\
\hline 5 & $1.80 \pm 0.90$ & $11.44 \pm 0.51$ & - & - & $0.04 \pm 0.02$ & - & $0.04 \pm 0.02$ \\
\hline 6 & - & - & - & - & $0.35 \pm 0.18$ & - & - \\
\hline 7 & $0.38 \pm 0.19$ & - & - & $0.13 \pm 0.06$ & $0.64 \pm 0.19$ & - & - \\
\hline 8 & - & - & - & $0.15 \pm 0.04$ & $0.29 \pm 0.17$ & - & - \\
\hline 9 & - & - & - & - & - & - & - \\
\hline 10 & - & - & - & - & - & - & - \\
\hline Total & $0.57 \pm 0.31$ & $11.69 \pm 4.17$ & - & $0.12 \pm 0.02$ & $0.12 \pm 0.05$ & $0.01 \pm 0.01$ & $0.01 \pm 0.07$ \\
\hline \multicolumn{8}{|c|}{ Counts model } \\
\hline$Z$ & -1.64 & 3.04 & - & -0.01 & 0.01 & - & - \\
\hline$P$ & 0.102 & 0.002 & - & 0.995 & 0.997 & - & - \\
\hline \multicolumn{8}{|c|}{ Zero-inflated model } \\
\hline
\end{tabular}

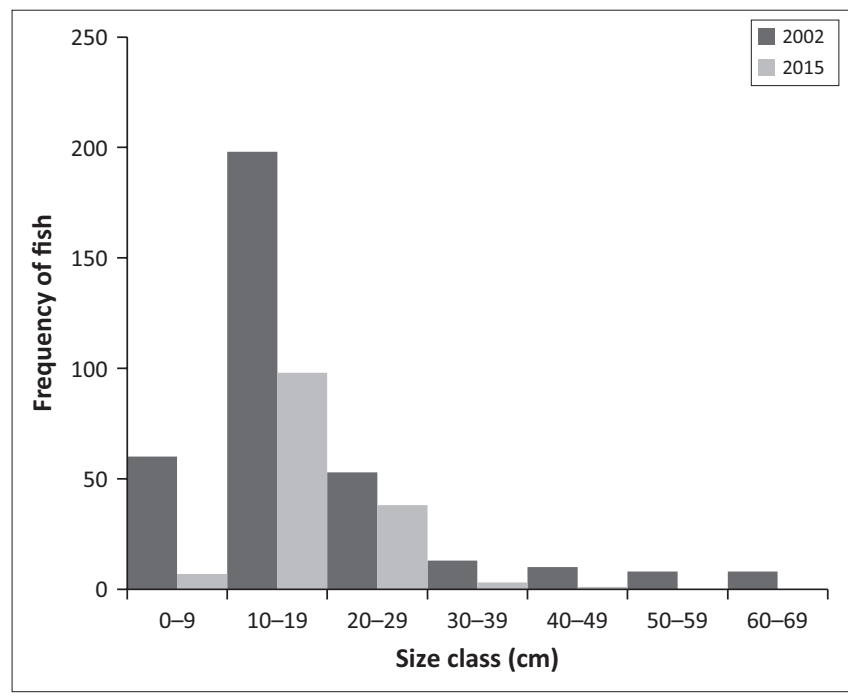

FIGURE 3: Size class distributions for the Barbus andrewi population in the upper Hex River in 2002 (Christie 2002; dark bars) and 2015 (light bars).

historically absent from the Hex River upstream of the N1 road bridge and that four indigenous fish species were present in this area (including the Cape galaxias, Galaxias zebratus Castelnau, 1861). Christie's (2002) survey revealed that $M$. dolomieu had since invaded the river between the N1 road bridge and the Glen Heatlie causeway by 2002 and had become the dominant species below the causeway, with small native species absent and only adult $B$. andrewi and O. mykiss present. In 2002, no M. dolomieu were recorded upstream of the causeway, and B. andrewi, S. capensis and P. burchelli were all relatively abundant above it (Table 1).

The results from the present survey imply that there have been further changes in the composition of the fish assemblage in the upper Hex River above the causeway since 2002. Importantly, the mean density estimate of B. andrewi in 2015 was more than fivefold lower than that recorded in 2015, and S. capensis, which was formerly present in the study area, was not recorded in 2015 (Table 1). It is acknowledged that although data collected from only two sampling occasions cannot be used to quantify population trends, the clear difference in the density of $B$. andrewi, an endangered regional endemic, between 2002 and 2015 is suggestive of a serious population decline and warrants immediate conservation attention.

Predation by, and competition with, non-native fishes has likely contributed to the observed declines in B. andrewi and S. capensis density estimates recorded in 2015. Although O. mykiss was the only non-native species recorded upstream of the causeway in 2002, our 2015 survey recorded an additional three non-natives in this section including M. dolomieu, C. gariepinus and C. carpio in this section of river. 
C. carpio and C. gariepinus have not been previously recorded in the Hex River. It is not known how M. dolomieu overcame the causeway barrier, or how C. carpio and C. gariepinus became resident in this area. Likely reasons include deliberate introductions by anglers above the causeway, escapees from off-stream farm dams situated upstream near De Doorns or invasions from downstream in the Breede mainstream (where C. carpio, C. gariepinus and M. dolomieu are common).

Predation by $M$. dolomieu on CFR fish assemblages is well documented, and studies show that they generally displace small-bodied native species and small size classes of largerbodied native species (Shelton, Day \& Impson 2014b; Weyl et al. 2013; Woodford et al. 2005), which could explain the low densities of $S$. capensis and small $(<10 \mathrm{~cm})$ B. andrewi relative to those recorded in 2002. Alternatively, the relatively low density of $B$. andrewi in 2015 may also be attributable to reduced reproductive output. Indeed, large $(>30 \mathrm{~cm})$ reproductively mature individuals were notably scarce in 2015, relative to 2002. The reason(s) for this difference is not entirely clear, but observed angling by farm labourers may be one (J.M. Shelton pers. obs., 2015) contributing factor. O. mykiss can also severely deplete native fish abundance in CFR streams, but its relatively low density in the upper Hex River may lessen its impact here (Shelton, Samways \& Day 2014a), hence its long-standing co-existence with native fishes in the study area. C. gariepinus is an opportunistic predator that has been implicated in declines of indigenous species when introduced outside of its native range in South Africa (Kadye \& Booth 2012) and C. carpio may compete with the native species for food and habitat (Skelton 2001).

The presence of non-native fishes above the Glen Heatlie causeway alone unlikely accounts for the recent marked reduction in native fish numbers, because the densities of non-native fishes in this section of river are relatively low ( $<1$ fish per $100 \mathrm{~m}^{2}$ for all non-native species). It is likely that a combination of threats including predatory alien fishes, sedimentation, water abstraction and pollution may be acting concurrently to reduce numbers of native fishes. The individual impacts of different threats can be difficult to disentangle, yet their combined effects appear to have resulted in severe declines of native fishes elsewhere in the CFR (Tweddle et al. 2009; Weyl et al. 2014).

In contrast to the decreases in density estimates for B. andrewi and S. capensis, the increase in P. burchelli density above Glen Heatlie causeway since 2002 was somewhat surprising. This may be a response to reduced competition for food and habitat from the other indigenous species, but the data collected in this study do not permit us to further address these hypotheses. The ongoing changes documented for the fish community in the upper Hex River is the cause for conservation concern, but finding ways to mitigate anthropogenic and alien fish pressures in an intensively farmed area is no easy task. Progress on this front will require a catchment-level management approach and commitment to reduce further impacts by stakeholders including farmers, the local municipality, CapeNature, Departments of Agriculture and Water and Sanitation, as well as anglers. Priority management actions in the upper Hex River should include improving habitat and water quality, as well as preventing further increases in the abundance and distribution of non-native fishes.

\section{Acknowledgements}

The authors thank Adrian Goemans and Mark Joscelyne for their time and assistance during the sampling of pools and Glenn Moncrieff for assistance with the statistical analysis. Finally, they thank landowners and CapeNature for permits and permission to access the study sites and supporting this project. K.J.E. provided support to S.G. though her NRF Incentive grant (76861). The data presented in this study were collected under CapeNature permit 0056-AAA04100116. J.M.S. received financial support from Stellenbosch University Subcommittee B for this research.

\section{Competing interests}

The authors declare that they have no financial or personal relationships that may have inappropriately influenced them in writing this article.

\section{Authors' contributions}

J.M.S. conceived the study, analysed the data and wrote the article; N.D.I. analysed the data and wrote the article; S.G. collected and analysed the data; K.J.E. conceived the study and wrote the article.

\section{References}

Christie, D., 2002, 'The distribution and population status of cape whitefish Barbus andrewi in the upper Hex River, Worcester and the associated impact of smallmouth bass Micropterus dolomieu', Honours Thesis, Department of Zoology, University of Cape Town.

Clark, B.M., Impson, N.D. \& Rall, J., 2009, 'Present status and historical changes in the fish fauna of the Berg River, South Africa', Transactions of the Royal Society of South Africa 64(2), 142-163. https://doi.org/10.1080/00359190909519249

De Moor, F.C. \& Day, J.A., 2013, 'Aquatic biodiversity in the Mediterranean region of South Africa', Hydrobiologia 719(1), 237-268. https://doi.org/10.1007/s10750013-1488-7

Ellender, B.R., Becker, A., Weyl, O.L.F. \& Swartz, E.R., 2012, 'Underwater video analysis as an non-destructive alternative to electrofishing for sampling imperilled headwater stream fishes', Aquatic Conservation 22(1), 58-65. https://doi. org/10.1002/aqc.1236

Hall, D.B., 2000, 'Zero-inflated poisson and binomial regression with random effects: A case study', Biometrics 56, 1030-1039. https://doi.org/10.1111/ j.0006-341X.2000.01030.x

Harrison, A.C., 1952, 'The Cape Witvis', Piscator 21, 24-26.

Holloway, A., Fortune, G. \& Chasi, V., 2010, 'Radar Western Cape 2010', Risk and development annual overview, PeriPeri Publications, University of Cape Town.

Impson, N.D., 2001, 'Threatened fishes of the world: Barbus andrewi Barnard, 1937 (Cyprinidae)', Environmental Biology of Fishes 61(1), 212. https://doi. org/10.1023/A:1011003302701

Impson, N.D., 2009, 'Hex River bulldozing. Unique fish community threatened', African Wildlife 63(2), 30-31.

Impson, N.D. \& Hamman, K.C.D., 2000, 'Conservation status, threats and future prospects for the survival of the freshwater fishes of the Western Cape Province, South Africa', in I.G. Cowx (ed.), Management and ecology of river fisheries, pp. 418-427, Blackwell Science, Blackwell, London.

Kadye, W.T. \& Booth, A.J., 2012, 'Detecting impacts of invasive non-native sharptooth catfish, Clarias gariepinus, within invaded and non-invaded rivers', Biodiversity and Conservation 21(8), 1997-2015. https://doi.org/10.1007/s10531-012-0291-5

Nel, J.L., Driver, A., Strydom, W.F., Maherry, A., Petersen, C., Hill, L. et al., 2011, Atlas of freshwater ecosystem priority areas in South Africa: Maps to support sustainable development of water resources, Water Research Commission Report No. TT 500/1, Water Research Commission, Pretoria, South Africa.

$\mathrm{R}$ Core Team, 2013, R: A language and environment for statistical computing, viewed 11 October 2016, from http://www.R-project.org 
Shelton, J.M., Day, J.A. \& Impson, N.D., 2014b, 'Preliminary evaluation of the impact of invasive smallmouth bass Micropterus dolomieu on native fish abundance in the Witte River, Cape Floristic Region, South Africa', African Zoology 49(2), in the Witte River, Cape Floristic Region, South
277-282. https://doi.org/10.3377/004.049.0219

Shelton, J.M., Samways, M.J. \& Day, J.A., 2014a, 'Predatory impact of non-native rainbow trout on endemic fish populations in headwater streams in the Cape Floristic Region of South Africa', Biological Invasions 17(1), 365-379. https://doi. org/10.1007/s10530-014-0735-9

Skelton, P.A., 2001, A complete guide to the freshwater fishes of Southern Africa Struik Publishers, Cape Town, South Africa.

Tweddle, D., Bills, R., Swartz, E.R., Coetzer, W., Da Costa, L., Engelbrecht, J. et al., 2009, 'The status and distribution of freshwater fishes', in W.R.T. Darwall, K.G. Smith, D. Tweddle \& P. Skelton (eds.), The status and distribution of freshwater biodiversity in southern Africa, pp. 21-37, IUCN, Gland, Switzerland.
Weyl, O.L.F., Ellender, B.R., Woodford, D.J. \& Jordaan, M.S., 2013, 'Fish distributions in the Rondegat River, Cape Floristic Region, South Africa, and the immediate impact of rotenone treatment in an invaded reach', African Journal of Aquatic Science 38(2), 201-209. https://doi.org/10.2989/16085914.2012.753 401

Weyl, O.L.F., Finlayson, B., Impson, N.D., Woodford, D.J. \& Steinkjer, J., 2014 'Threatened endemic fishes in South Africa's Cape Floristic Region: A new beginning for the Rondegat River', Fisheries 39(6), 270-279. https://doi.org/10. 1080/03632415.2014.914924

Woodford, D.J., Impson, N.D., Day, J.A. \& Bills, I.R., 2005, 'The predatory impact of invasive alien smallmouth bass, Micropterus dolomieu, on indigenous fishes in a Cape Floristic Region mountain stream', African Journal of Aquatic Science 30(2), 167-173. https://doi.org/10.2989/16085910509503852 